\title{
Noble Metal-Assisted Surface Plasmon Resonance Immunosensors
}

\author{
Jin-Ha Choi ${ }^{1,+} \mathbb{D}$, Jin-Ho Lee ${ }^{2,+} \mathbb{D}$, Joohyung Son ${ }^{1}$ and Jeong-Woo Choi ${ }^{1,3, *}$ \\ 1 Department of Chemical and Biomolecular Engineering, Sogang University, Seoul 04107, Korea; \\ jinhachoi@sogang.ac.kr (J.-H.C.); organoid@sogang.ac.kr (J.S.) \\ 2 School of Biomedical Convergence Engineering, Pusan National University, Yangsan 50612, Korea; \\ leejh@pnu.ac.kr \\ 3 Department of Biomedical Engineering, Sogang University, Seoul 04107, Korea \\ * Correspondence: jwchoi@sogang.ac.kr; Tel.: +(82)-2-705-8480; Fax: +(82)-2-718-1976 \\ + These authors contributed equally to this work.
}

Received: 21 January 2020; Accepted: 11 February 2020; Published: 13 February 2020

\begin{abstract}
For the early diagnosis of several diseases, various biomarkers have been discovered and utilized through the measurement of concentrations in body fluids such as blood, urine, and saliva. The most representative analytical method for biomarker detection is an immunosensor, which exploits the specific antigen-antibody immunoreaction. Among diverse analytical methods, surface plasmon resonance (SPR)-based immunosensors are emerging as a potential detection platform due to high sensitivity, selectivity, and intuitive features. Particularly, SPR-based immunosensors could detect biomarkers without labeling of a specific detection probe, as typical immunosensors such as enzyme-linked immunosorbent assay (ELISA) use enzymes like horseradish peroxidase (HRP). In this review, SPR-based immunosensors utilizing noble metals such as Au and Ag as SPR-inducing factors for the measurement of different types of protein biomarkers, including viruses, microbes, and extracellular vesicles (EV), are briefly introduced.
\end{abstract}

Keywords: surface plasmon resonance; noble nanoparticle; immunosensor; label-free detection; biosensor

\section{Introduction}

The optoelectronic phenomenon of surface plasmon resonance (SPR), which is widely utilized in optical biosensors, was established from studies involving excitation of surface plasmons on metallic surfaces, especially noble metals [1-4]. When metallic surfaces are exposed to light, a photon is trapped near the metallic surface and prompts the electrons to move as a single electrical entity, which is known as surface plasmon (SP). This oscillation of electrons in a metal film (PSPR, propagating surface plasmon resonance) leads to the formation of an electromagnetic field that exponentially decays out from the surface, also known as the evanescent field [5,6]. Differently, when a surface plasmon is confined on nanomaterials, this unique physical property is highly localized around the nanoparticle, leading to a non-propagating localized surface plasmon with a specific frequency (LSPR, localized surface plasmon resonance) $[7,8]$. Although these optical phenomena have attracted interest in various fields, use is most prominent in the field of biosensor development [9-13].

Both PSPR and LSPR-based biosensors utilize refractive index changes to sensitively detect mass changes based on the molecular interaction that occurs on the surface of a metal film or nanoparticle [14-17]. For example, in the case of a planar surface, the binding of bio/chemical molecules perturbs the plasmon and leads to a shift of the resonance angle of the incoming photons [18]. Thus, no additional labeling materials are required to transduce the binding event, and the method also 
provides quantitative real-time measurements with remarkable sensitivity over a broad range of bio/chemical molecules [19]. Although PSPR-based sensors is known to have a much higher refractive index sensitivity compare to LSPR-based sensors, as the sensitivity of PSPR-based sensor is highly affected by the penetration depth of evanescence field (ca. $200 \mathrm{~nm}$ ) [20-22], their sensitivity towards $\mathrm{bio} / \mathrm{chemical}$ molecular interaction is similar [13]. However, due to the much shorter electromagnetic decay length on the nanoparticles compared to gold films, which allow confining the response to a smaller sensing volume, LSPR-based sensor is known to be more sensitive to small molecular binding and less sensitive to bulk effects [23]. Considering these advantages, both PSPR- and LSPR-based analytical methods have been extensively utilized to investigate bio/chemical molecular interactions for diagnostic purposes.

PSPR- and LSPR-based biosensors commonly use antibodies as a bio-receptors for recognition of the target of interest. Recent approaches have been extensively applied to utilize new bio-receptors such as aptamers and imprinted polymers for replacement of antibodies; however, antibody-based assays are still considered the primary choice for developing PSPR- and LSPR-based biosensors, owing to their superior affinity, selectivity, and stability $[24,25]$. To this end, a wide range of antibody immobilization methods has been developed to achieve optimal consistency while maintaining the activity of immobilized antibodies. The formation of well-ordered interfaces is also considered as an essential aspect to achieve a reliable and sensitive sensor platform [24].

In this review, we will provide a selective overview of the recent advances in the development of highly sensitive PSPR- and LSPR-based immunosensors as excellent clinical diagnostic systems. Sections will focus on protein biomarkers, viral agents, microbes, and extracellular vesicles as selective biomarkers. Finally, the future perspective of the development of SPR- and LSPR-based analytical methods such as miniaturization will be discussed. We hope that this review will provide brief and concise information on the development of SPR- and LSPR-based biosensors and emphasize research from various disciplines for further development and improvement of SPR- and LSPR-based analytical methods for more significant biomedical applications.

\section{Analytical Methods for Protein Biomarkers}

Proteins in biological fluids are promising candidates as indicators of disease risk and allow for early diagnosis for more effective treatment. Taking advantage of PSPR and LSPR-based analytical methods has created extensive applications in the development of immunoassays for diagnosing diseases with protein biomarkers [26,27]. Mohseni et al. have reported on the development of SPR-based immunosensors for real-time and label-free detection of recombinant human matrix metalloproteinases-9 (MMP-9) as a biomarker for malignant tumor progression and metastasis [28] (Figure 1a). A carboxymethyl dextran hydrogel sensor chip was utilized for the immobilization of anti-MMP-9 monoclonal antibodies through amine coupling reagents and further experiments. Through optimization of parameters (e.g., equilibrium dissociation constant (KD) and maximum binding capacity (Rmax)) that affect the SPR-based sensing property, the limit of detection (LOD) was found to be $8 \mathrm{pg} / \mathrm{mL}$ for MMP-9 in saliva samples with linearity in the range of $10 \sim 200 \mathrm{ng} / \mathrm{mL}$. 
(a)

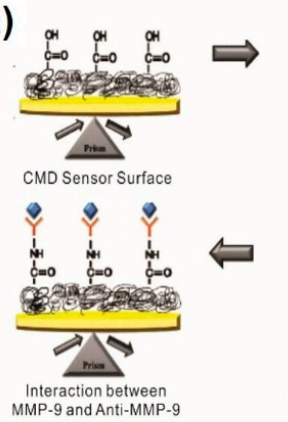

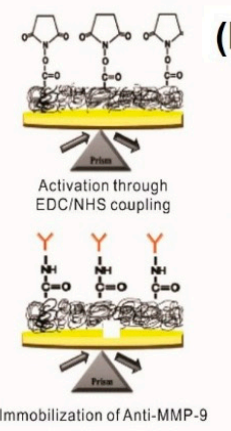

(b)

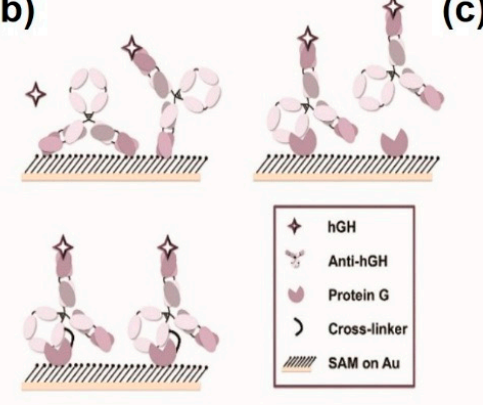

(c)

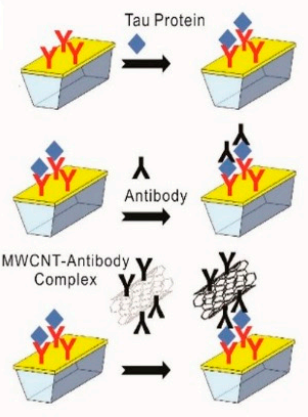

Figure 1. Propagating surface plasmon resonance (PSPR)-based immunosensors for protein biomarker detection. (a) Detection of human matrix metalloproteinases-9 by SPR-based immunosensor; (b) signal enhancement of SPR-based immunosensor by protein $\mathrm{G}$ meditated site direct immobilization of antibody; (c) signal amplification of SPR-based immunosensor by utilizing multi-walled carbon nanotubes as a mass enhancer. (a) Figure reproduced with permission from [28], (C) 2016 Elsevier; (b) Figure reproduced with permission from [29], (C) 2015 RSC Publishing; (c) Figure reproduced with permission from [30], (C) 2017 Elsevier.

As the SPR signal is based on the molecular interaction of a receptor (antibody) and a target analyte (antigen), Makaraviciute et al. have shown that meditating protein $\mathrm{G}$ for site-directed antibody immobilization can amplify the analytical signal 3.5 times higher than randomly oriented antibodies [29] (Figure 1b). Typically, random immobilization can achieve higher surface coverages while site-directed immobilization provides better sensitivities [31]. Based on these findings, authors have detected human growth hormone (hGH) at a LOD of $21.9 \mathrm{ng} / \mathrm{mL}$, with a linear detection range from $66.4 \sim 199 \mathrm{ng} / \mathrm{mL}$. However, due to the small mass of a protein molecule, one of the foremost methods to enhance the SPR-based sensor response is the employment of additional materials as high mass labels [32]. For this purpose, Lisi et al. modified multi-walled carbon nanotubes (MWCNTs) and decorated them with the secondary antibody as a mass enhancer to amplify the signal for Tau protein detection [30] (Figure 1c). Functionalization of antibodies with MWCNTs significantly enhances sensor response up to $10^{2}$ fold, which was challenging to obtain with the protein analyte itself or by employing conventional unconjugated sandwich assays [30]. Similarly, Pawula et al. utilized gold nanoparticles (AuNPs) as a mass enhancer to amplify the sandwich assay-based SPR immuno-sensor response for cardiac troponin $\mathrm{T}(\mathrm{cTnT})$ detection [33].

In a different approach, the LSPR mechanism has been utilized for the development of analytical methods for the detection of protein biomarkers [34-36]. In typical LSPR-based analytical methods, the bio/chemical interaction on the surface of metallic nanoparticles leads to an increase of the refractive index of a local medium, resulting in a resonant wavelength shift. Based on this unique plasmon response of single AuNP and antibody-antigen binding activity, Lee et al. described label-free multiplex detection of cancer biomarkers including $\alpha$-fetoprotein (AFP), carcinoembryonic antigen (CEA), and prostate-specific antigen (PSA) [37] (Figure 2a). The LSPR-based plasmonic biosensor was fabricated by immobilizing AuNPs on a hydrophilic-hydrophobic patterned glass slide in a site-specific manner, and it functionalized antibodies that selectively recognize target proteins. The binding activity between the antibody and antigen (target) was monitored through spectral changes resulting from the local refractive index of individual AuNPs. Owing to the outstanding properties of the LSPR mechanism, the proposed platform exhibits excellent selectivity and sensitivity with a LOD of $6.28 \mathrm{pg} / \mathrm{mL}, 16.9 \mathrm{pg} / \mathrm{mL}$ and 284 $\mathrm{fg} / \mathrm{mL}$ for AFP, CEA, and PSA, respectively, from patient-mimicked serum. As the intrinsic refractive index sensitivity is highly affected by the frequency-dependent dielectric function, size, and shape of materials, Jia et al. have demonstrated that $\mathrm{Au} / \mathrm{Ag}$ bimetallic NPs could preserve a sharper plasmonic peak with more sensitive plasmonic responses, compared to monometallic AuNPs [38] (Figure 2b). Two sequential evaporations of gold and silver on a glass substrate, followed by annealing, resulted in a uniform size and shape distribution of bimetallic NPs. As proof of concept, bovine serum albumin 
(BSA) was applied as a model protein marker and a LOD of $0.01 \mathrm{ng} / \mathrm{mL}$ was observed under the optimized conditions.

(a)

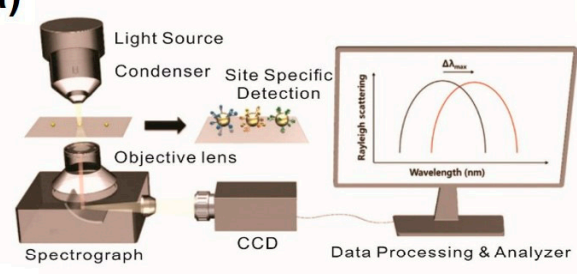

(c)

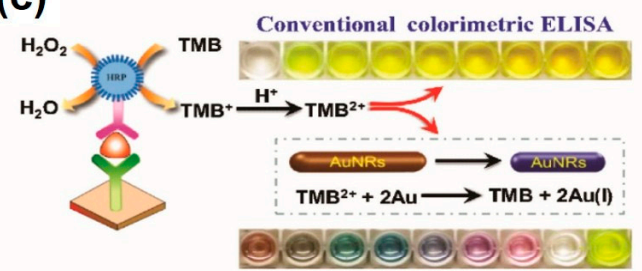

(b)

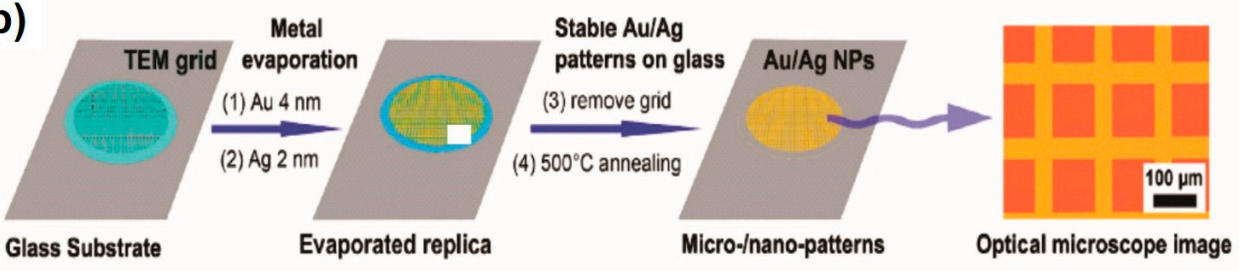

Figure 2. Localized surface plasmon resonance (LSPR)-based immunosensors for protein biomarker detection. (a) Selective recognition of multiplex cancer biomarkers by LSPR immunosensor; (b) signal enhancement of LSPR-based immunosensor by employing bimetallic nanostructures; (c) LSPR band shift based on the GNR etching resulted by TMB reaction. (a) Figure reproduced with permission from [37], (C) 2015 Elsevier; (b) Figure reproduced with permission from [38], (C) 2014 American Chemical Society; (c) Figure reproduced with permission from [39], (C) 2017 Elsevier.

Conversely, Ma et al. demonstrated that the LSPR peak shift could also occur through structural changes of noble-metal nanostructures [39]. Authors have described that the product (TMB2+) of horseradish peroxidase (HRP)-catalyzed oxidation of 3, 3', 5, 5' -tetramethylbenzidine (TMB) can etch out the gold nanorods (GNRs), which generates vivid color responses based on the LSPR peak shift through structural changes [39] (Figure 2c). Based on this finding, researchers have utilized GNRs in a commercially available HRP-TMB immunoassay system for visual quantification of CEA and PSA with the naked eye. Similarly, the SPR and LSPR phenomena have been widely utilized in the development of different types of analytical methods for the determination of protein biomarkers [40]. Recent research on SPR- and LSPR-based analytical methods for protein marker detection are compared in Table 1.

Table 1. Comparison of SPR and LSPR-based immunosensors for protein biomarker detection.

\begin{tabular}{|c|c|c|c|c|c|}
\hline Method & Working Principle & Target & $\begin{array}{l}\text { Correlation } \\
\text { Range }\end{array}$ & $\begin{array}{l}\text { Detection } \\
\text { Limit }\end{array}$ & Ref \\
\hline \multirow{6}{*}{ PSPR } & $\begin{array}{c}\text { Site-directed antibody } \\
\text { immobilization based on } \\
\text { protein } \mathrm{A} / \mathrm{G}\end{array}$ & $\begin{array}{l}\text { C-reactive protein } \\
\text { (CRP) }\end{array}$ & $1.2 \sim 80 \mathrm{ng} / \mathrm{mL}$ & $1.2 \mathrm{ng} / \mathrm{mL}$ & [27] \\
\hline & $\begin{array}{c}\text { Antibody immobilization } \\
\text { based on EDC/NHS coulping }\end{array}$ & $\begin{array}{l}\text { metalloproteinases-9 } \\
\text { (MMP-9) }\end{array}$ & $10 \sim 200$ ng/mL & $8 \mathrm{pg} / \mathrm{mL}$ & [28] \\
\hline & $\begin{array}{l}\text { Site-directed antibody } \\
\text { immobilization based on } \\
\text { protein } G\end{array}$ & $\begin{array}{l}\text { human growth } \\
\text { hormone }(\mathrm{hGH})\end{array}$ & $\underset{*}{66.4 \sim 199 \mathrm{ng} / \mathrm{mL}}$ & $21.9 \mathrm{ng} / \mathrm{mL}^{*}$ & [29] \\
\hline & $\begin{array}{l}\text { Sandwich assay based on } \\
\text { AuNP-antibody conjugate }\end{array}$ & $\begin{array}{c}\text { Carcinoembryonic } \\
\text { Antigen (CEA) }\end{array}$ & $0 \sim 2.5 \mathrm{ng} / \mathrm{mL}$ & $17.8 \mathrm{pg} / \mathrm{mL}$ & [32] \\
\hline & $\begin{array}{l}\text { Sandwich assay based on } \\
\text { MWCNT-antibody conjugate }\end{array}$ & Tau Protein & $\begin{array}{l}9.87 \sim 78.9 \\
\mathrm{ng} / \mathrm{mL} *\end{array}$ & $9.87 \mathrm{ng} / \mathrm{mL}^{*}$ & [30] \\
\hline & $\begin{array}{l}\text { Sandwich assay based on } \\
\text { AuNP-antibody conjugate }\end{array}$ & $\begin{array}{l}\text { Cardiac troponin } \mathrm{T} \\
(\mathrm{cTnT})\end{array}$ & $0.5 \sim 40 \mathrm{ng} / \mathrm{mL}$ & $0.5 \mathrm{ng} / \mathrm{mL}$ & [33] \\
\hline
\end{tabular}


Table 1. Cont.

\begin{tabular}{|c|c|c|c|c|c|}
\hline Method & Working Principle & Target & $\begin{array}{c}\text { Correlation } \\
\text { Range }\end{array}$ & $\begin{array}{l}\text { Detection } \\
\text { Limit }\end{array}$ & Ref \\
\hline \multirow{9}{*}{ LSPR } & $\begin{array}{c}\text { nanorods (GNR) } \\
\text { functionalized with poly } \\
\text { (N-isopropylacrylamide) } \\
\text { (PNIPAAM) }\end{array}$ & Troponin-T (TnT) & $\begin{array}{c}7.6 \sim 9.1 \times 10^{11} \\
\mathrm{fg} / \mathrm{mL}\end{array}$ & $8.4 \mathrm{fg} / \mathrm{mL}$ & [34] \\
\hline & $\begin{array}{l}\text { LSPR band shift based on } \\
\text { interparticle crosslinking }\end{array}$ & $\begin{array}{l}\text { Staphylococcal } \\
\text { enterotoxin A } \\
\text { (SEA) }\end{array}$ & $0 \sim 250 \mathrm{ng} / \mathrm{mL}$ & $5 \mathrm{ng} / \mathrm{mL}$ & [35] \\
\hline & $\begin{array}{c}\text { Core/shell nanoparticle } \\
\text { Au@AgNPs and Ag@AuNPs }\end{array}$ & $\begin{array}{l}\text { Staphylococcal } \\
\text { enterotoxin A } \\
\text { (SEA) }\end{array}$ & $0 \sim 500 \mathrm{ng} / \mathrm{mL}$ & $5.4 \mathrm{ng} / \mathrm{mL}$ & [36] \\
\hline & Single AuNP & $\begin{array}{l}\alpha \text {-fetoprotein } \\
\text { (AFP) }\end{array}$ & $\begin{array}{c}69 \sim 6.9 \times 10^{7} \\
\mathrm{fg} / \mathrm{mL}^{*}\end{array}$ & $6.28 \mathrm{pg} / \mathrm{mL}^{*}$ & [37] \\
\hline & Single AuNP & $\begin{array}{l}\text { Carcinoembryonic } \\
\text { antigen (CEA) }\end{array}$ & $\begin{array}{c}180 \sim 1.8 \times 10^{8} \\
\mathrm{fg} / \mathrm{mL}^{*}\end{array}$ & $16.9 \mathrm{pg} / \mathrm{mL}^{*}$ & [37] \\
\hline & Single AuNP & $\begin{array}{l}\text { Prostate specific } \\
\text { antigen (PSA) }\end{array}$ & $\begin{array}{c}28.4 \sim 2.84 \times 10^{6} \\
\mathrm{fg} / \mathrm{mL} *\end{array}$ & $284 \mathrm{fg} / \mathrm{mL}^{*}$ & [37] \\
\hline & $\begin{array}{c}\mathrm{Au} / \mathrm{Ag} \text { Bimetallic } \\
\text { nanostructures modified with } \\
\text { polydopamine films }\end{array}$ & $\begin{array}{l}\text { Bovine serum } \\
\text { albumin (BSA) }\end{array}$ & $0.01 \sim 100 \mathrm{ng} / \mathrm{mL}$ & $0.01 \mathrm{ng} / \mathrm{mL}$ & [38] \\
\hline & $\begin{array}{l}\text { LSPR band shift based on the } \\
\text { GNR etching resulted by TMB } \\
\text { reaction }\end{array}$ & $\begin{array}{l}\text { Carcinoembryonic } \\
\text { antigen (CEA) }\end{array}$ & $0 \sim 60 \mathrm{ng} / \mathrm{mL}$ & $2.5 \mathrm{ng} / \mathrm{mL}$ & [39] \\
\hline & $\begin{array}{l}\text { LSPR band shift based on the } \\
\text { GNR etching resulted by TMB } \\
\text { reaction }\end{array}$ & $\begin{array}{l}\text { Prostate specific } \\
\text { antigen (PSA) }\end{array}$ & $0 \sim 1275 \mathrm{pg} / \mathrm{mL}$ & $75 \mathrm{pg} / \mathrm{mL}$ & [39] \\
\hline
\end{tabular}

\section{Analytical Methods for Viral Agents}

A sensitive and selective analytical method for pathogenic viral agents is also critical for the successful diagnosis and treatment of diseases [41]. Most of the diseases caused by viruses such as flu and the common cold can be self-recovered by the innate immune response; however, some viruses evade this mechanism and cause life-threatening diseases such as Ebola, dengue hemorrhagic fever, and acquired immune deficiency syndrome [42-44]. Conventional methods for diagnosing infection with viral agents, such as serologic tests and enzyme-linked immunosorbent assays (ELISA), are not sensitive enough and are time-consuming $[45,46]$. To this end, SPR has gained interest from the medical field for the development of highly sensitive and selective analytical methods for viral agents.

Chang et al. developed an intensity-modulated surface plasmon resonance (IM-SPR)-based immunosensor as a label-free, rapid test for avian influenza A H7N9 [47] (Figure 3a). To maximize sensitivity, authors employed a newly developed antibody which specifically recognizes the H7N9 virus but no other clinical human influenza isolates. By incorporating a highly specific antibody, a 20-fold increase in sensitivity, as compared to ELISA, was observed in less than $10 \mathrm{~min}$. The detection limit in samples spiked with nasal mucosa from flu-like syndrome patients was observed to be 402 copies $/ \mathrm{mL}$, which is significantly lower than the detection limit of conventional influenza detection approaches including rapid influenza diagnostic tests and quantitative reverse transcription-polymerase chain reaction (qRT-PCR). Similarly, Loureiro et al. developed a PSPR-based immunoassay for the rapid diagnosis of dengue viral infection [49]. In this method, a neutravidin-biotin mediated monoclonal antibody is immobilized on a thin gold film as the sensing element. The binding interaction between 
the monoclonal antibody and the dengue virus (DENV) results in a pronounced thickness change that is optically recorded in real-time using an integrated microfluidic setup. The developed method is applicable even when testing complex biological fluids composed of non-specific binding interferences. The experimental LOD was estimated to be $2 \times 10^{4}$ particles $/ \mathrm{mL}$. Jahanshahi et al. also developed a PSPR-based dengue diagnostic test by targeting the DENV immunoglobulin M (IgM) [48] (Figure 3b). The authors immobilized the four different dengue virus serotype antigens on a biochip surface as ligands instead of immobilizing DENV-specific antibodies. Note that, here the antibody was considered as a target instead of antigen. The SPR angle change clearly showed variation between patient serum antibody titers categorized as high positive (HP), mid positive (MP) and low positive (LP). Each dengue virus serotype has a linear slope variation on the SPR angle, which allows for the distinction of HP, MP, and LP titers. Furthermore, samples of tick-borne encephalitis (negative dengue NS1) and hepatitis C (negative dengue IgM) viruses were tested to ensure the high sensitivity and specificity of the proposed method. Consequently, the ratio of each dengue serotype in the samples was able to be determined with $83 \% \sim 93 \%$ sensitivity and $100 \%$ specificity.

(a)

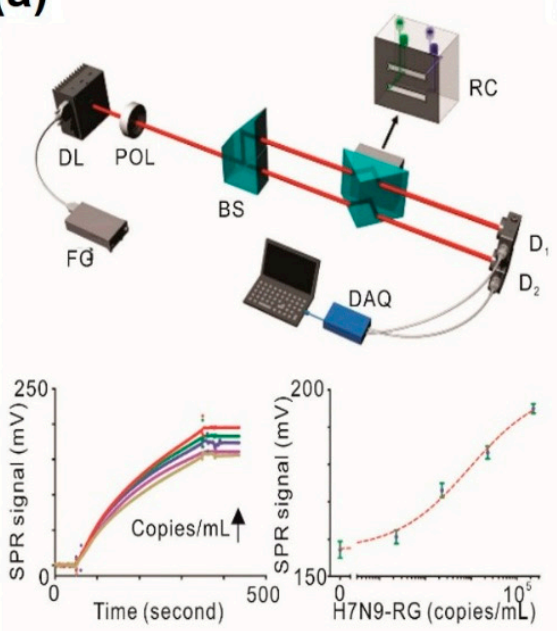

(b)

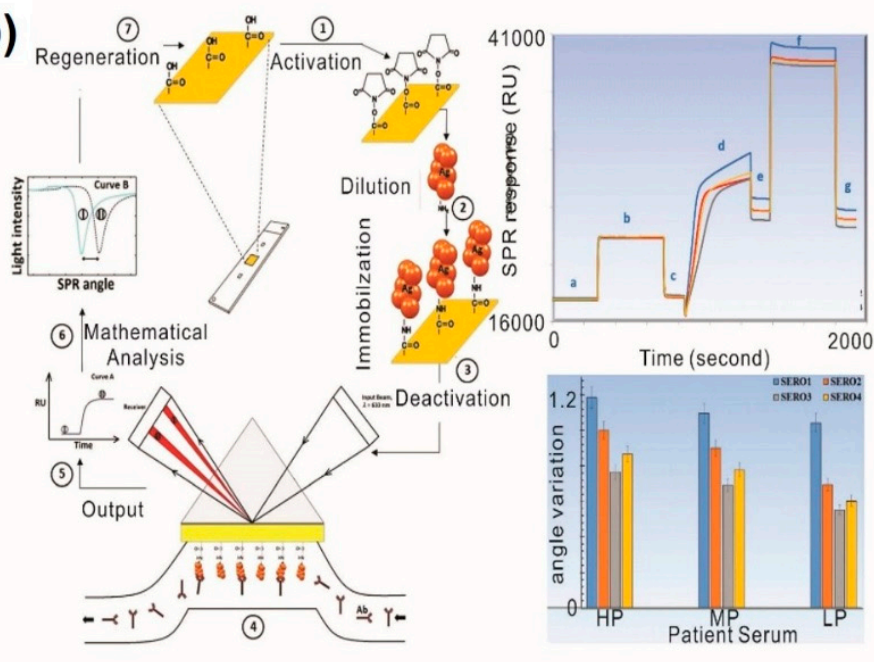

Figure 3. SPR-based immunosensors for viral agents detection. (a) Detection of Avian Influenza A H7N9 Virus by SPR-based immunosensor; (b) selective recognition of four different serotypes of dengue virus by SPR-based immunosensor from clinical samples. (a) Figure reproduced with permission from [47], (C) 2018 American Chemical Society; (b) Figure reproduced with permission from [48], (C) 2014 Springer Nature.

A few studies have also reported on the development of analytical methods for viruses based on the LSPR mechanism as well. Luo et al. developed a novel immunosensor to detect Newcastle disease virus (NDV) by integrating excessively tilted fiber grating (Ex-TFG) coated with AuNP [50]. Owing to the local surface plasmon resonance (LSPR) effect of the AuNP, the detection limit and sensitivity of the proposed analytical method was approximately 5 10 times improved compare to conditions without AuNP treatment. By monitoring the resonance wavelength shift, the LOD was estimated as $\sim 25 \mathrm{pg} / \mathrm{mL}$. Similarly, Lee et al. have proposed a simple analytical method for HIV virus-like particle detection based on the LSPR mechanism [51] (Figure 4a). Researchers fabricated highly ordered circular-shaped $\mathrm{Au}$ nanopatterns on a transparent indium tin oxide substrate through an electrochemical deposition method and utilized it for HIV detection. The presence of HIV was characterized through absorbance shifts resulting from changes in the refractive index on the surface of Au nanopatterns without any additional labeling materials. Furthermore, Kim et al. integrated hetero-assembled AuNPs by the sandwich assay method to detect the hepatitis B surface antigen (HBsAg) in a more sensitive manner [52] (Figure $4 \mathrm{~b}$ ). By forming a hetero-assembled sandwich-immunoassay, the LOD was improved up to $100 \mathrm{fg} / \mathrm{mL}$ of HBsAg, while a single-layered LSPR-based analytical device using AuNPs was able to 
detect as low as $10 \mathrm{pg} / \mathrm{mL}$. As can be seen, both PSPR and LSPR-based analytical methods are widely utilized for the sensitive and selective detection of pathogenic viral agents. Recent research on SPRand LSPR-based analytical methods for viral agent detection are compared in Table 2.

(a)
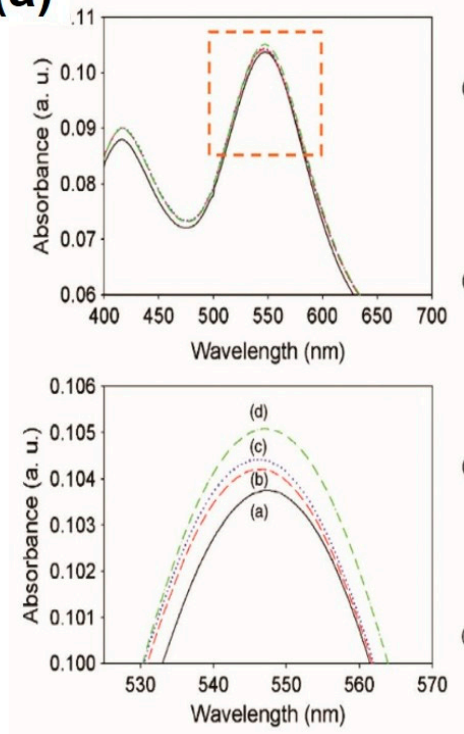

(d)

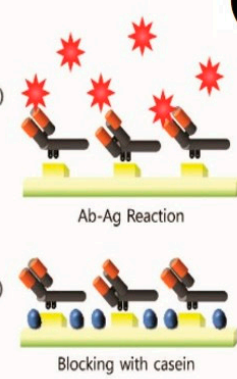

(b)

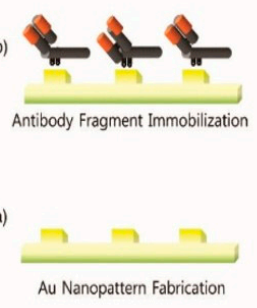

(b)

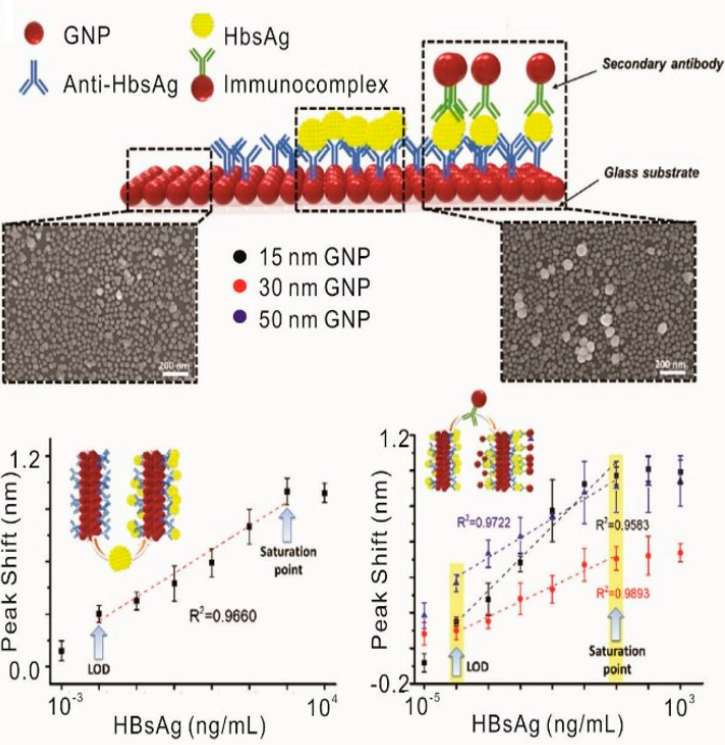

Figure 4. LSPR-based immunosensors for viral agent detection. (a) Detection of HIV-1 virus by LPSR-based immunosensor; (b) signal amplification of LSPR-based immunosensor by forming hetero-assembled gold nanoparticles based on the sandwich assay. (a) Figure reproduced with permission from [51], (C) 2013 Elsevier, (b) Figure reproduced with permission from [52], (C) 2018 Elsevier.

Table 2. Comparison of SPR and LSPR-based immunosensors for viral agent detection.

\begin{tabular}{|c|c|c|c|c|c|}
\hline Method & Working Principle & Target & Correlation Range & $\begin{array}{l}\text { Detection } \\
\text { Limit }\end{array}$ & Ref \\
\hline \multirow[b]{2}{*}{ PSPR } & $\begin{array}{l}\text { Generation of new } \\
\text { antibody }\end{array}$ & $\begin{array}{l}\text { Avian Influenza A } \\
\text { H7N9 Virus }\end{array}$ & $\begin{array}{c}2.3 \times 10^{2} \sim 2.3 \times 10^{5} \\
\text { copies } / \mathrm{mL}\end{array}$ & 402 copies/mL & [47] \\
\hline & $\begin{array}{l}\text { Antibody } \\
\text { immobilization based } \\
\text { on neutravidin-biotin }\end{array}$ & $\begin{array}{l}\text { Dengue Virus } \\
\text { Serotype } 2 \& 3\end{array}$ & Not stated & $\begin{array}{l}2 \times 10^{4} \\
\text { particles } / \mathrm{mL}\end{array}$ & [49] \\
\hline \multirow{3}{*}{ LSPR } & $\begin{array}{l}\text { Electrochemically } \\
\text { deposited AuNPs }\end{array}$ & $\begin{array}{c}\text { Human } \\
\text { immunodeficiency } \\
\text { Virus }\end{array}$ & $0 \sim 200 \mathrm{pg} / \mathrm{mL}$ & $25 \mathrm{pg} / \mathrm{mL}$ & [51] \\
\hline & $\begin{array}{l}\text { hetero-assembled } \\
\text { AuNP based on } \\
\text { sandwich-immunoassay }\end{array}$ & $\begin{array}{l}\text { Hepatitis B surface } \\
\text { antigen }\end{array}$ & $\begin{array}{c}200 \sim 1.25 \times 10^{5} \\
\mathrm{fg} / \mathrm{mL}\end{array}$ & $200 \mathrm{fg} / \mathrm{mL}$ & [52] \\
\hline & $\begin{array}{l}\text { Tilted fiber grating } \\
\text { coated with AuNP }\end{array}$ & $\begin{array}{l}\text { Newcastle disease } \\
\text { virus }\end{array}$ & $100 \sim 1 \times 10^{6} \mathrm{fg} / \mathrm{mL}$ & $100 \mathrm{fg} / \mathrm{mL}$ & {$[50]$} \\
\hline
\end{tabular}

\section{Analytical Methods for Pathogenic Microbes}

Several pathogenic microbes critically threaten humans as a result of ease of infection and long latency periods [53]. Therefore, pathogenic microbes such as bacteria are important targets for early diagnosis and treatment in medicine, public health, and food safety [54]. Infectious diseases are the leading cause of disease and death worldwide, with millions of casualties each year. In particular, infectious diseases from bacteria are most challenging in low-income countries [55,56]. Representatively, Escherichia coli (E. coli) O157:H7 and Salmonella are the leading causes of bacterial diseases [53,57]. The primary cause of mortality is an inaccurate and time-consuming diagnosis of bacterial infection. Therefore, the development of more specific and sensitive analytical platforms that can be employed at 
the point of care are urgently needed. For bacterial detection, immunoreaction-based assays including enzyme-linked immunosorbent assays (ELISAs) are usually utilized to detect particular surface proteins [58-60]. A variety of surface antigens present on a cell surface can bind to a specific antibody, and the expressed antigen can vary depending on the type of bacteria. Therefore, immune-based analytical methods could be applied to detect bacteria and diagnose a bacterial infection. However, the conventional immunoassay is time-consuming and costly due to the specialist technical staff and equipment required. Among recent strategies for more efficient detection of bacteria, SPR-based bacterial sensors have been developed [61,62]. Previously, we developed SPR-based biosensors for bacterial detection using the specific immune reaction between a surface antigen on the bacteria and a specific antibody on the Au plate [63,64]. For the oriented immobilization of antibodies, protein G was pre-immobilized on the Au surface. The pathogen binding of the antibody-immobilized Au plate was determined by SPR spectroscopy. In result, four different pathogenic microbes, including Escherichia coli (E.Coli) O157:H7, Salmonella Typhimurium, Legionella pneumophila, and Yersinia enterocolitica could be selectively detected with high efficiency. In addition, Vibrio cholerae (V. cholerae) $\mathrm{O} 1$ was successfully measured by SPR analysis on an 11-mercaptoundecanoic acid (MUA) and antibody-immobilized Au plate. The detection range was between $10^{5}$ and $10^{9}$ cells $/ \mathrm{mL}$. Since then, various types of SPR-based biosensing platforms have been developed for bacterial detection. In this section, recently developed pathogenic bacteria detection systems will be introduced briefly.

As described above, several pathogenic microbes have been measured by SPR-based immunoassay, which utilizes a noble metal such as $\mathrm{Au}$ as a plasmonic effector. Taheri et al. developed a sensitive $V$. cholerae detection system using antibodies against recombinant outer membrane protein (antiOmpW) [65]. The high-affinity interaction between anti-OmpW and OmpW $\left(\mathrm{K}_{\mathrm{D}}=2.4 \times 10^{-9} \mathrm{M}\right)$ induced sensitive detection of $V$. cholerae, with a detection limit of 43 cells $/ \mathrm{mL}$ and a high $\mathrm{R}^{2}$ value $(>0.98)$. Makhneva et al. demonstrated the use of a plasma polymer-functionalized Au surface for effective antibody immobilization [66]. An anti-Salmonella antibody was successfully functionalized on an Au surface and the bacteria was detected at a level as low as $10^{5} \mathrm{CFU} / \mathrm{mL}$ with a wide linear response by both SPR and quartz crystal microbalance (QCM) analytical methods simultaneously. Chen et al. developed a singleplex immunoassay for Salmonella serotypes (S. Enteritidis, S. Heidelberg, and S. Typhimurium) to evaluate the potential of SPR imaging in specific pathogenic bacteria detection [67]. LODs were found to be $2.1 \times 10^{6} \mathrm{CFU} / \mathrm{mL}$ in buffer solution and $8.9 \times 10^{7} \mathrm{CFU} / \mathrm{mL}$ of a microflora mixture. Masdor et al. found that Campylobacter jejuni was sensitively detected by an SPR analytical method using a subtractive inhibition assay (SIA), which measured the unbound anti-Campylobacter jejuni from the supernatant [68] (Figure 5a). This SIA-based SPR immunosensor exhibited outstanding sensitivity with a LOD of $131 \pm 4 \mathrm{CFU} / \mathrm{mL}$ and a $95 \%$ confidence interval of 122 to $140 \mathrm{CFU} / \mathrm{mL}$, with high specificity. It could detect the minimum infectious dose of Campylobacter jejuni (below 500 $\mathrm{CFU} / \mathrm{mL}$ ), making the method suitable as a rapid and sensitive method for the early detection of microbe infection. For signal enhancement and sensitive detection of pathogenic microbes, Farka et al. described a label-free detection system for Salmonella Typhimurium at levels as low as $10^{4}$ CFU/mL within $10 \mathrm{~min}$ [69] (Figure 5b). In addition, a horseradish peroxidase (HRP)-labeled secondary detection antibody was specifically attached to Salmonella Typhimurium, and it produced precipitation of 4-chloro-1-naphthol to benzo-4-chlorocyclohexadienone. It could induce signal enhancement and result in a LOD of $100 \mathrm{CFU} / \mathrm{mL}$ with a linear range up to $10^{6} \mathrm{CFU} / \mathrm{mL}$.

Noble metal nanostructures have been frequently used for microbe detection systems to enhance functions such as specificity and sensitivity. Haddada et al. developed an Au nanoparticle-antibody bioconjugate, which was engineered by covalently linking anti-staphylococcal enterotoxin A (SEA) antibodies, for a colorimetric assay by localized surface plasmon resonance (LSPR) [70]. SEA was measured in both the $\mathrm{ng} / \mathrm{mL}$ and $\mu \mathrm{g} / \mathrm{mL}$ working ranges with a $5 \mathrm{ng} / \mathrm{mL} \mathrm{LOD}$. In addition, it could be stored for 1 year at $4{ }^{\circ} \mathrm{C}$ without loss of detection performance. Zou et al. utilized $\mathrm{Fe}_{3} \mathrm{O}_{4} @ \mathrm{Au}$ nanoparticles as a magneto-plasmonic nanoprobe for the amplification of SPR signals. The $\mathrm{Fe}_{3} \mathrm{O}_{4} @ \mathrm{Au}$ nanoparticles can concentrate the electric charge density and widen the surface area of the antibody 
functionalization. The electronic coupling effect could be enhanced and the SPR signals amplified as high as 30-fold above the LOD. Using this system, tuberculosis caused by Mycobacterium tuberculosis was successfully detected at a LOD of $0.1 \mathrm{ng} / \mathrm{mL}$. Zheng et al. developed a microfluidic biosensor with Au and magnetic nanoparticles for simple, rapid, and sensitive detection of E. coli O157:H7 [71]. Two different anti-E. coli antibodies were functionalized on the magnetic nanoparticle and polystyrene microsphere, forming a sandwich structure with E. coli O157:H7. Aggregation of the Au nanoparticles was induced through the crosslinking of phenolic hydroxyl moieties in tyramine by catalase, which is catalyzing hydrogen peroxide. The resulting color change was measured using a smartphone imaging application to detect E. coli $\mathrm{O} 157: \mathrm{H} 7$ with good specificity and sensitivity $(50 \mathrm{CFU} / \mathrm{mL}$ of LOD) (Figure 6a). Zhang et al. showed a sandwich-immunoassay system for staphylococcal enterotoxin serotype A (SEA) by the color change of Au nanoparticles [72]. On a transparent slide glass, Au nanoparticles could be attached when SEA was captured, and the color appeared as red at the detection spot. The detection range was 10 to $50 \mathrm{ng} / \mathrm{mL}$ with a LOD of $1.5 \mathrm{ng} / \mathrm{mL}$. Optical fiber with a coating of a noble metal such as Au or Ag is also frequently used for microbe detection. Arcas et al. reported on an SPR-based optical fiber biosensor for the detection of E. coli by immunoassay [73]. In this study, U-shaped plastic optical fiber was coated with Au for the induction of the SPR phenomenon. In $70 \mathrm{~nm}$ and $100 \mathrm{~nm}$ Au-coated optical fiber, the SPR effect is predominant, and it can be used to detect bacteria at concentrations as low as $1.5 \times 10^{3} \mathrm{CFU} / \mathrm{mL}$. Kaushik et al. developed a molybdenum disulfide $\left(\mathrm{MoS}_{2}\right)$ nanosheets functionalized optic fiber to enhance the signal of an SPR immunosensor for the sensitive detection of E. coli [74] (Figure 6b). The two-dimensional nanosheet $\left(\mathrm{MoS}_{2}\right)$ was anchored to the surface of the Au coated optic fiber and monoclonal antibodies were immobilized on the functionalized nanosheets via hydrophobic interactions. This label-free immunosensor displays better performance (detection limit $94 \mathrm{CFU} / \mathrm{mL}$ ) and a higher sensitivity $(2.9 \mathrm{~nm} / 1000 \mathrm{CFU} / \mathrm{mL}$; $3135 \mathrm{~nm} /$ refractive index unit (RIU)) than conventional optic fiber biosensors (detection limit 391 $\mathrm{CFU} / \mathrm{mL}$, sensitivity $0.6 \mathrm{~nm} / 1000 \mathrm{CFU} / \mathrm{mL}, 1646 \mathrm{~nm} / \mathrm{RIU}$ ), with a rapid detection time (about $15 \mathrm{~min}$ ). In this way, a noble metal-assisted nanostructure or optic fiber could improve the performances of SPR-based immunosensor such as sensitivity, selectivity and reduced assay time. The recent researches on SPR and LSPR-based analytical methods for bacterial detection are compared in Table 3.
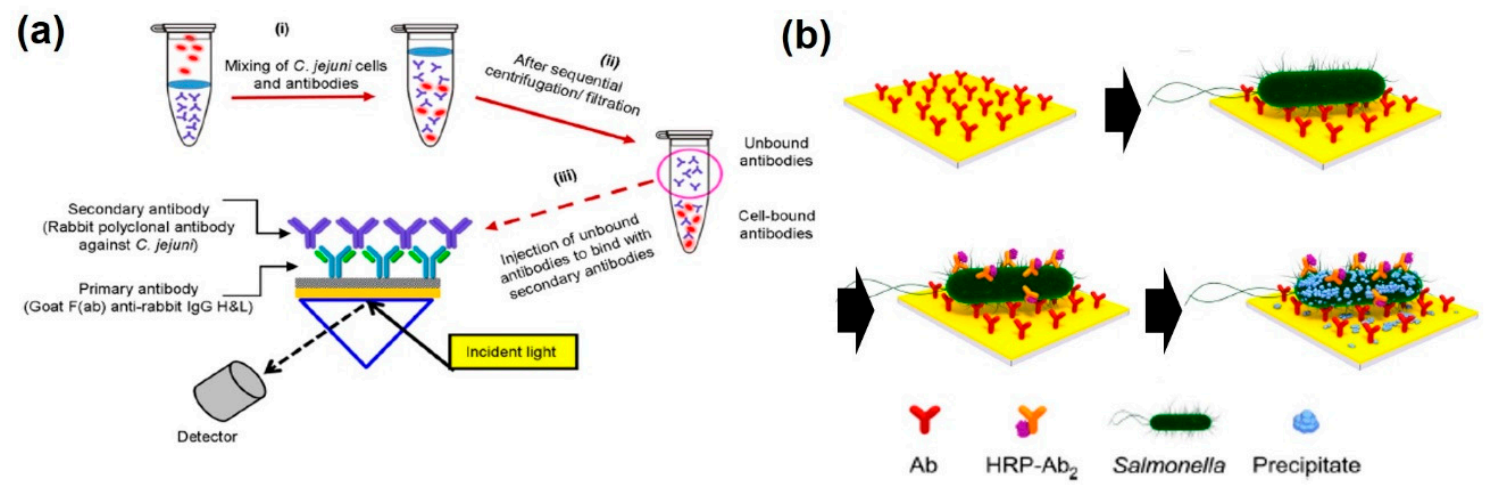

Figure 5. PSPR-based immunosensors for pathogenic microbe detection. (a) The specificity of developed C. jejuni assay using unbounded secondary antibody detection; (b) SPR chip with the immobilized capture antibody, binding of Salmonella, HRP-Ab conjugate, and HRP-catalyzed conversion of 4-chloro-1-naphthol to insoluble benzo-4-chlorocyclohexadienone. (a) Figure reproduced with permission from [68], (C) 2019 Springer Nature; (b) Figure reproduced with permission from [69], (C) 2016 American Chemical Society. 
(a)

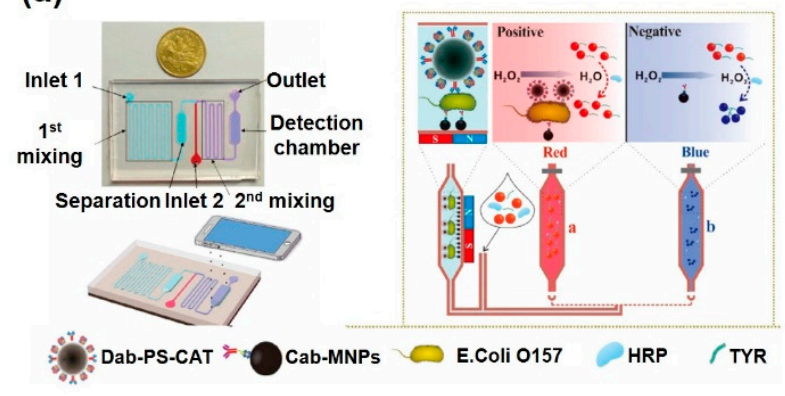

(b)

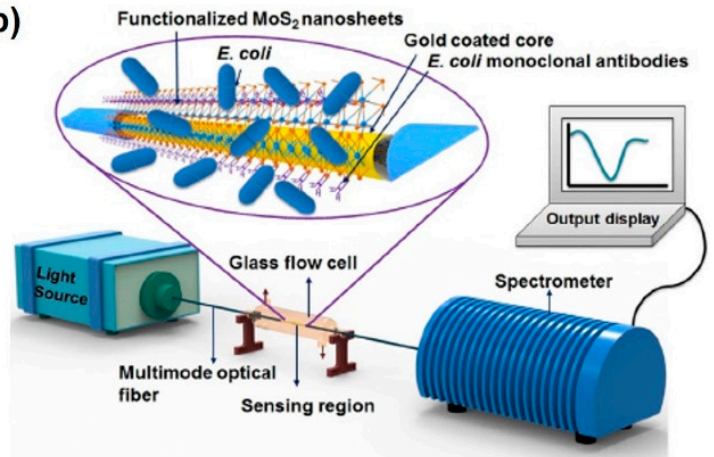

Figure 6. LSPR and optic fiber mediated SPR-based immunosensors for pathogenic microbe detection. (a) Colorimetric immunosensors with microfluidic device for the detection of E. coli O157 by aggregation of Au nanoparticles; (b) fiber optic SPR immunosensor based on $\mathrm{MoS}_{2}$ nanosheet for the detection of $\mathrm{E}$. coli. (a) Figure reproduced with permission from [71], (c) 2019 Elsevier, (b) Figure reproduced with permission from [74], (C) 2019 Elsevier.

Table 3. Comparison of SPR and LSPR-based immunosensors for bacterial detection.

\begin{tabular}{|c|c|c|c|c|c|}
\hline Method & Working Principle & Target & $\begin{array}{l}\text { Correlation } \\
\text { Range } \\
\text { (CFU/mL) }\end{array}$ & $\begin{array}{l}\text { Detection } \\
\text { Limit } \\
(\mathrm{CFU} / \mathrm{mL})\end{array}$ & Ref \\
\hline \multirow{7}{*}{ PSPR } & $\begin{array}{l}\text { Immobilization of antibody } \\
\text { against recombinant outer } \\
\text { membrane protein (anti-OmpW) } \\
\text { of Vibrio cholerae on Au chip }\end{array}$ & Vibrio Cholerae & $10^{1}-10^{5}$ & 10 & [65] \\
\hline & $\begin{array}{l}\text { Functionalization of plasma } \\
\text { polymers (PPs) on Au surface } \\
\text { for a stable immobilization of } \\
\text { antibodies }\end{array}$ & $\begin{array}{l}\text { Salmonella } \\
\text { Typhimurium }\end{array}$ & $10^{5}-10^{8}$ & $10^{5}$ & [66] \\
\hline & $\begin{array}{c}\text { Immobilization of antibody } \\
\text { using microarray spotter and } \\
\text { flowed the samples on the Au } \\
\text { chip }\end{array}$ & $\begin{array}{l}\text { Salmonella } \\
\text { Typhimurium }\end{array}$ & $\begin{array}{c}5.14 \times 10^{6}-5.14 \\
\times 10^{8}\end{array}$ & $2.1 \times 10^{6}$ & [67] \\
\hline & $\begin{array}{l}\text { Detection of unbounded } \\
\text { anti-Campylobacter Jejuni by } \\
\text { the anti-rabbit IgG on Au chip }\end{array}$ & $\begin{array}{l}\text { Campylobacter } \\
\text { Jejuni }\end{array}$ & $5-5 \times 10^{7}$ & $131 \pm 4$ & {$[68]$} \\
\hline & $\begin{array}{l}\text { Measurement of precipitated } \\
\text { 4-chloro-1-naphthol by the } \\
\text { HRP-tagged anti-Salmonella }\end{array}$ & $\begin{array}{l}\text { Salmonella } \\
\text { Typhimurium }\end{array}$ & $10^{2}-10^{6}$ & $10^{2}$ & [69] \\
\hline & $\begin{array}{l}\text { Light escaping from optic fiber } \\
\text { due to immunocapture of } \\
\text { Escherichia coli }\end{array}$ & $\begin{array}{c}\text { Escherichia coli } \\
\text { O157:H7 }\end{array}$ & Not stated & $1.5 \times 10^{3}$ & [73] \\
\hline & $\begin{array}{c}\text { Functionalization of } \mathrm{MoS}_{2} \\
\text { nanosheet and anti- Escherichia } \\
\text { coli on Au-coated optical fiber }\end{array}$ & $\begin{array}{c}\text { Escherichia coli } \\
\text { O157:H7 }\end{array}$ & $1 \times 10^{4}-8 \times 10^{4}$ & 94 & {$[74]$} \\
\hline LSPR & $\begin{array}{c}\text { Color change by the } \\
\text { tyramine-functionalized } \mathrm{Au} \\
\text { nanoparticles and } \\
\text { catalases-functionalized } \\
\text { polystyrene beads, immobilized } \\
\text { by Escherichia coli }\end{array}$ & $\begin{array}{c}\text { Escherichia coli } \\
\text { O157:H7 }\end{array}$ & $5 \times 10^{1}-5 \times 10^{4}$ & 50 & [71] \\
\hline
\end{tabular}




\section{Analytical Methods for Extracellular Vesicles (EVs)}

In animal cells, extracellular vesicles (EVs) are released by budding from the membrane of a mother cell and are transferred to other cells [75-78]. EVs can be produced inside the multivesicular endosome (MVE). When MVE is fused to the cell membrane, the secreted EVs are called exosomes, with sizes of $<200 \mathrm{~nm}$ diameter and contain several biomolecules, such as proteins, mRNA, miRNA, and lipids, with signature characteristics of their mother cells $[79,80]$. Therefore, secreted exosomes can represent their mother cells, including the cell type, cell cycle, and stage of cancer. Particularly, exosomes play key roles in tumorigenesis and cancer progression, including immunosuppression, angiogenesis, and metastasis [78,81-83]. Based on these characteristics, exosomes are one of the best candidates to be used as potential biomarkers for noninvasive cancer. Cancer-associated antigens are highly enriched on the surface of exosomes from cancer cells. Therefore, utilizing their surface biomarkers is the most promising approach for the simple and rapid detection of cancers. For the development of biosensors, tetraspanins, such as CD9, CD63, CD81, and CD82, on the surface of exosomes are normally employed as targets for total exosome detection. On the other hand, specific proteins on the surface of exosomes such as carcinoembryonic antigen (CEA), epithelial cell adhesion molecule (EpCAM), human epidermal growth factor receptor 2 (HER2), insulin-like growth factor receptor (IGFR), latent membrane protein 1 (LMP1), melanoma cell adhesion molecule (MCAM), and prostate-specific membrane antigen (PSMA) can be utilized for the detection of cancer cells. In this section, SPR-based immunosensors will be discussed for the determination of exosome levels, which are related to several cancers.

SPR is a label-free, real-time analysis technique and is extremely sensitive to biological binding events occurring within $200 \mathrm{~nm}$ of wave depth of the Au layer. This distance directly matches the dimension of exosomes. Therefore, SPR-based biosensors are perfectly suited for the study of exosomes. The substrate used for reported SPR biosensors for exosome detection has been primarily based on Au-based plates. Picciolini et al. demonstrated the SPR imaging assay using an antibody array, which could bind to the surface protein of the exosome, on an Au plate for the separation and characterization of multiple exosomes from diverse neuronal cells [84] (Figure 7a). Exosomes from oligodendrocytes and neurons were measured with high sensitivity and selectivity. Subsequently, quantification of CD81 and GM1 (monosialotetrahexosylganglioside), exosome-specific proteins of each subpopulation, were successfully conducted by applying a second antibody on the exosome. These results verify the extreme inconsistency of exosome composition, even though the mother cells were of similar origin. Sina et al. reported a real-time, label-free detection method for breast cancer-related exosomes from complex biological samples using a SPR immunosensor [85]. Using this simple platform, HER2-specific exosomes were captured and detected on an anti-HER2-functionalized Au plate, at concentrations as low as $0.83 \times 10^{7} / \mathrm{mL}$.

(a)

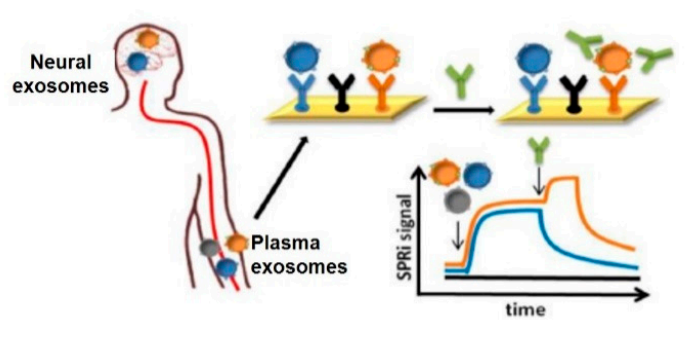

(b)

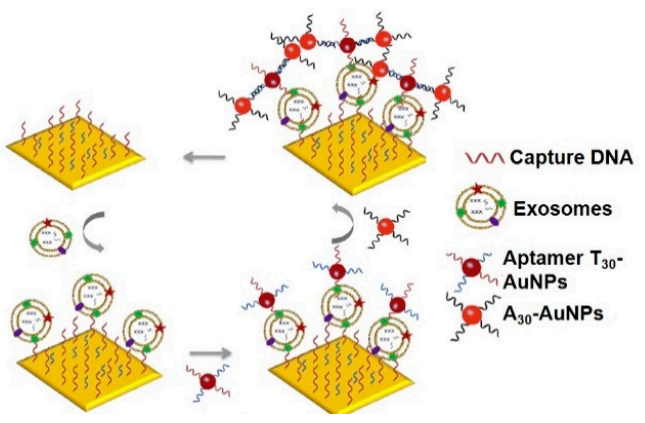

Figure 7. PSPR-based immunosensors for extracellular vesicle detection. (a) Detection and characterization of different brain-derived exosomes by SPR imaging; (b) dual Au nanoparticle-assisted signal amplification of SPR signals for determination of breast cancer-related exosomes. (a) Figure reproduced with permission from [84], (C) 2018 American Chemical Society; (b) Figure reproduced with permission from [86], (C) 2019 Elsevier. 
Diverse nanostructures have been used for signal amplification of SPR immunosensors. Particularly, Au nanostructures have shown higher sensitivity to local refractive index variation near the Au nanosurface. Im et al. developed periodic Au nanohole arrays for label-free, high-throughput analysis of exosomes derived from ovarian cancer cells [87]. The Au nanoholes designed for a probing depth below $200 \mathrm{~nm}$, can be easily matched to exosome size (below $100 \mathrm{~nm}$ ) for highly sensitive detection. Moreover, the transmission setup allows for miniaturization of the system and tightly packed sensing arrays for the easy application of field diagnostic tests. Therefore, this SPR-based immunosensor is readily scalable for parallel measurements up to $10^{5}$ sensing spots. Thakur et al. described random arrays of self-assembled Au nanoislands for mass-produced sensitive and low-cost LSPR biosensors for tumor-related exosomes [88]. The advantage of this sensing system is the ability to distinguish exosomes from multivesicular vesicles (MVs) isolated from A-549, SH-SY5Y cells, blood serum, and urine in a lung cancer mouse model. This sensor could detect exosome concentrations ranging from 0.194 to $100 \mu \mathrm{g} / \mathrm{mL}$. Bathini et al. detailed an Au nanoisland-assisted exosome detection platform with a streptavidin-biotin-polyethylene glycol (PEG)-venceremin (Vn96) complex [89]. Vn96, is a synthetic peptide, having a high affinity for heat shock proteins (HSPs) on the surface of exosomes. Each of the nanoislands can capture nine exosomes, meaning that the developed Au nanoisland platform can capture a much higher number of extracellular vesicles, thus offering a wide detection range from early stages to advanced stages of cancer. Wang et al. described a $30 \mathrm{~nm}$-sized dual Au nanoparticle-assisted SPR immunosensor for the sensitive detection of exosomes released from MCF-7 breast cancer cells [86] (Figure 7b). The aptamer/ $\mathrm{T}_{30}$-linked Au nanoparticles were bound to the target exosomes and $\mathrm{A}_{30}$-coated $\mathrm{Au}$ nanoparticles could be captured on the aptamer $/ \mathrm{T}_{30}$-linked Au nanoparticles through A-T hybridization. Therefore, target exosomes could be detected at concentrations as low as $5 \times 10^{3} / \mathrm{mL}$ by dual amplification between Au plate-Au nanoparticle and Au-Au nanoparticle. Raghu et al. discussed Au nanoplasmonic pillar arrays developed using nano- and micro-fabrication techniques for single exosome detection by an LSPR imaging analytical method [90] (Figure 8a). By sizing the individual nanopillar to approximately $100 \mathrm{~nm}$, similar to the size of an exosome, it is possible to observe in situ single-exosome binding events in sub-femtomolar concentrations of exosomes via LSPR imaging signal. This approach results in a three orders of magnitude improvement of sensitivity over previously reported real-time, multiplexed platforms with an $80 \mathrm{~nm}$ Au-capped quartz nanopillar, which could minimize nonspecific binding events.

(a)
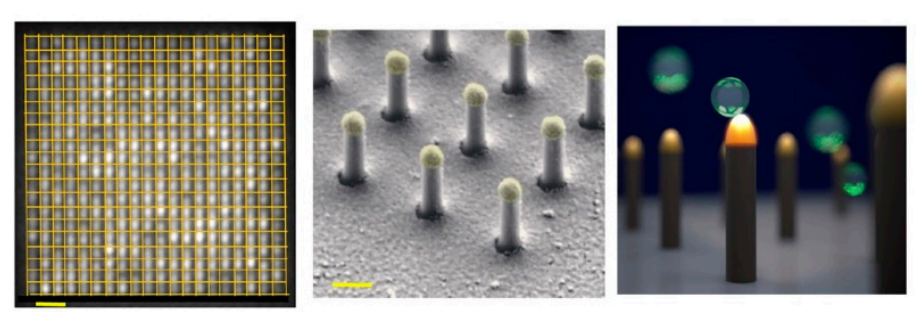

(b)

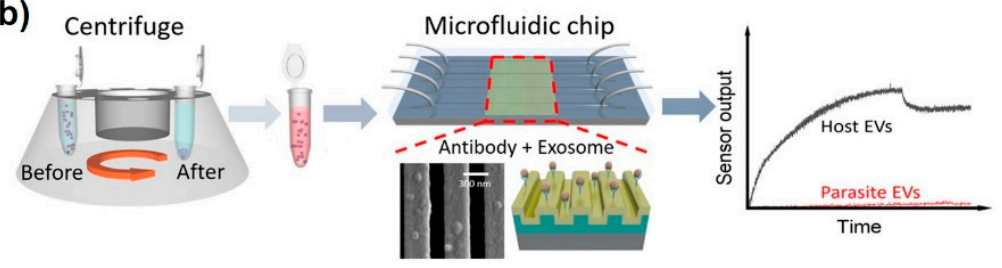

Figure 8. LSPR-based immunosensors for extracellular vesicle detection. (a) LSPRi sensor chip and high-magnification false-colored SEM image showing individual nanopillars, allowing digitized exosome detection. Scale bars are $1 \mu \mathrm{m}$ and $200 \mathrm{~nm}$, respectively; (b) microfluidic photonic crystal biosensor for the detection of host and parasitic exosomes. (a) Figure reproduced with permission from [90], (C) 2018 Plos one, (b) Figure reproduced with permission from [91], (C) 2018 American Chemical Society. 
Meanwhile, the development of microfluidics technologies provides novel exosome analysis platforms with excellent potential for the characterization of several diseases using a liquid biopsy without invasive methods. The microfluidic platforms have revealed great capacity for exosome analysis in clinical applications, including reduction of sample consumption, high-throughput analysis, reduction of cross-contamination, and the automation of isolation-detection to improve efficiency and reliability. Wang et al. reported that a microfluidic-integrated photonic crystal biosensor was successfully developed to distinguished host and parasitic exosomes released by the murine macrophage cell line J774A.1 and parasitic nematodes such as Ascaris suum [91] (Figure 8b). The surface of a photonic crystal was functionalized to anti-CD63, which could capture exosomes secreted by host cells. This biosensor exhibited a $2.18 \times 10^{9} / \mathrm{mL}$ LOD and is low-cost and disposable with a rapid assay time. The recent researches on SPR and LSPR-based analytical methods for exosomes detection are compared in Table 4.

Table 4. Comparison of SPR and LSPR-based immunosensors for exosome detection.

\begin{tabular}{|c|c|c|c|c|c|}
\hline Method & Working Principle & Target & $\begin{array}{l}\text { Correlation } \\
\text { Range }\end{array}$ & $\begin{array}{l}\text { Detection } \\
\text { Limit }\end{array}$ & Ref \\
\hline \multirow[t]{2}{*}{ PSPR } & $\begin{array}{l}\text { Immobilization of spotted } \\
\text { anti-CD81 and -GM1 on Au } \\
\text { chip }\end{array}$ & $\begin{array}{l}\text { Exosomes from diverse } \\
\text { neuronal cells }\end{array}$ & $1-10 \mu \mathrm{g} / \mathrm{mL}$ & Not stated & [84] \\
\hline & $\begin{array}{l}\text { Immobilization of anti-HER2 } \\
\text { on Au chip for detection of } \\
\text { breast cancer-derived exosome }\end{array}$ & $\begin{array}{l}\text { Breast cancer-derived } \\
\text { exosomes }\end{array}$ & $\begin{array}{c}0.83-3.31 \times \\
10^{7} / \mathrm{mL}\end{array}$ & $\begin{array}{r}0.83 \times \\
10^{7} / \mathrm{mL}\end{array}$ & [85] \\
\hline \multirow{5}{*}{ LSPR } & $\begin{array}{c}\text { Functionalization of PEG and } \\
\text { anti-CD63 on periodic Au } \\
\text { nanohole }\end{array}$ & $\begin{array}{c}\text { Ovarian } \\
\text { cancer-derived } \\
\text { exosomes }\end{array}$ & $\begin{array}{c}4.03 \times \\
10^{5}-1.32 \times \\
10^{9} / \mathrm{mL}\end{array}$ & $\begin{array}{r}4.03 \times \\
10^{5} / \mathrm{mL}\end{array}$ & [87] \\
\hline & $\begin{array}{l}\text { Immobilized anti-CD9 on } \\
\text { self-assembly } \mathrm{Au} \text { islands for } \\
\text { exosome detection }\end{array}$ & $\begin{array}{l}\text { Exosomes from A-549 } \\
\text { and SH-SY5Y cells }\end{array}$ & $\begin{array}{l}0.194-100 \\
\mu \mathrm{g} / \mathrm{mL}\end{array}$ & $\begin{array}{r}0.194 \\
\mu \mathrm{g} / \mathrm{mL}\end{array}$ & [88] \\
\hline & $\begin{array}{l}\text { Venceremin-functionalized } \mathrm{Au} \\
\text { nanoparticles on Au islands } \\
\text { for capture the exosomes }\end{array}$ & $\begin{array}{l}\text { Breast cancer-derived } \\
\text { exosomes }\end{array}$ & Not stated & $9 / \mu \mathrm{m}^{2}$ & [89] \\
\hline & $\begin{array}{l}\text { Functionalization of } \\
\text { anti-CD63 on nanopillar array }\end{array}$ & $\begin{array}{l}\text { Breast cancer-derived } \\
\text { exosomes }\end{array}$ & Not stated & $1 \times 10^{5} / \mathrm{mL}$ & [90] \\
\hline & $\begin{array}{l}\text { Line shaped-Au nanopatterns } \\
\text { with immobilization of } \\
\text { anti-CD63 }\end{array}$ & $\begin{array}{c}\text { Murine } \\
\text { macrophage-derived } \\
\text { exosomes }\end{array}$ & $\begin{array}{c}2 \times 10^{9}-2 \times \\
10^{11} / \mathrm{mL}\end{array}$ & $\begin{array}{c}2.18 \times \\
10^{9} / \mathrm{mL}\end{array}$ & [91] \\
\hline
\end{tabular}

\section{Future Perspective and Conclusions}

One of the final goals of the biosensors is the development of point-of-care testing (POCT) system for the prompt and precise therapy. In order that SPR immunosensors can be reached on the criteria for the point-of-care system, there should be integrated technologies such as portable platform, disposable chip, and miniaturization of the analytical machine. Recently, there has been presented a smartphone-integrated analytical system, enabling rapid diagnosis with connection to medical doctors and institutions. In addition, disposable-type chips have been also developed as a user convenience device with a simple operation such as color-change detection. On this wise, the SPR immunosensors have a great potential to utilize measurement of biomarkers due to their inherent label-free, cost-effective analysis with the rapid response time. Because of these advantages, SPR-based immunosensors will also facilitate the high-throughput and multiplex measurement of several biomarkers with the integration of the microfluidic system. On the other hand, the sensitivity is not high enough for the measurement of biomarkers in small volumes of body fluid, and it is not an intuitive color-change based method, with the exception of that based on Au nanoparticles [20,24]. Therefore, there have been several 
attempts to improve the sensitivity, that has been improved using magnetic activity, meta-surfaces, grating or photonic crystals $[13,21,22,92]$. Meanwhile, the plasmonic effect, which induces SPR phenomena, can induce other phenomena that can be applied to the development of immunosensors, including surface-enhanced Raman scattering (SERS), fluorescence resonance energy transfer (FRET), and metal-enhanced fluorescence (MEF). If the SERS, FRET, MEF-based analytical methods could be integrated with an SPR-based immunosensor using plasmonic effects, targets could be better measured and the shortcomings of each analytical method could be complemented [7,93-97]. Various plasmonic-based analytical methods each have advantages with noble metals and nanostructures, and it could be possible to develop higher performance immunosensors using an integrated platform.

In this review, we introduced recent developments of SPR-based immunosensors with noble metals and nanostructures for the improvement of functionalities as efficient biosensors. The great advantage of this analytical method is in situ, label-free detection. It could result in the development of an immunosensor capable of measuring a target in a rapid, simple, and cost-effective manner. Currently, there are considerable shortcomings in SPR-based immunosensor systems pertaining to the challenges of highly sensitive detection. However, the integration of a plasmonic-based sensing system will offer a breakthrough platform for developing effective immunosensors for early diagnosis and POCT of various diseases, which, in turn, can improve biomedical, pharmaceutical, and clinical applications.

Author Contributions: The manuscript was written through the contributions of all authors. All authors have read and agreed to the published version of the manuscript.

Funding: This research was supported by the Basic Science Research Program through the National Research Foundation of Korea (NRF) funded by the Ministry of Education (No.2018R1A6A3A11051465), and the National Research Foundation of Korea (NRF) grant funded by the Korea government (MSIT) (No.2019R1A2C3002300) and Basic Science Research Program through the National Research Foundation of Korea (NRF) funded by the Ministry of Education (No.2016R1A6A1A03012845).

Conflicts of Interest: The authors declare no conflicts of interest.

\section{References}

1. Gong, C.; Leite, M.S. Noble Metal Alloys for Plasmonics. Acs Photonics 2016, 3, 507-513. [CrossRef]

2. Haes, A.J.; Zou, S.L.; Schatz, G.C.; Van Duyne, R.P. Nanoscale optical biosensor: Short range distance dependence of the localized surface plasmon resonance of noble metal nanoparticles. J. Phys. Chem B 2004, 108, 6961-6968. [CrossRef]

3. Sugawa, K.; Tahara, H.; Yamashita, A.; Otsuki, J.; Sagara, T.; Harumoto, T.; Yanagida, S. Refractive Index Susceptibility of the Plasmonic Palladium Nanoparticle: Potential as the Third Plasmonic Sensing Material. Acs Nano 2015, 9, 1895-1904. [CrossRef] [PubMed]

4. Haes, A.J.; Zou, S.L.; Schatz, G.C.; Van Duyne, R.P. A nanoscale optical biosensor: The long range distance dependence of the localized surface plasmon resonance of noble metal nanoparticles. J. Phys. Chem B 2004, 108, 109-116. [CrossRef]

5. Schasfoort, R.B. Handbook of surface plasmon resonance; Royal Society of Chemistry: London, UK, 2017.

6. Rich, R.L.; Myszka, D.G. Advances in surface plasmon resonance biosensor analysis. Curr Opin Biotechnol 2000, 11, 54-61. [CrossRef]

7. Yang, L.; Lee, J.H.; Rathnam, C.; Hou, Y.; Choi, J.W.; Lee, K.B. Dual-Enhanced Raman Scattering-Based Characterization of Stem Cell Differentiation Using Graphene-Plasmonic Hybrid Nanoarray. Nano Lett 2019, 19, 8138-8148. [CrossRef]

8. Eustis, S.; El-Sayed, M.A. Why gold nanoparticles are more precious than pretty gold: Noble metal surface plasmon resonance and its enhancement of the radiative and nonradiative properties of nanocrystals of different shapes. Chem. Soc. Rev. 2006, 35, 209-217. [CrossRef]

9. Jain, P.K.; Huang, X.; El-Sayed, I.H.; El-Sayad, M.A. Review of some interesting surface plasmon resonance-enhanced properties of noble metal nanoparticles and their applications to biosystems. Plasmonics 2007, 2, 107-118. [CrossRef]

10. Nguyen, H.H.; Park, J.; Kang, S.; Kim, M. Surface plasmon resonance: a versatile technique for biosensor applications. Sensors 2015, 15, 10481-10510. [CrossRef] 
11. Brolo, A.G. Plasmonics for future biosensors. Nature Photon. 2012, 6, 709-713. [CrossRef]

12. Belotelov, V.; Akimov, I.; Pohl, M.; Kalish, A.; Kasture, S.; Vengurlekar, A.; Gopal, A.; Kotov, V.; Yakovlev, D.; Zvezdin, A. Intensity magnetooptical effect in magnetoplasmonic crystals. In Proceedings of Journal of Physics: Conference Series; IOP Publishing: Bristol, UK, 2011; p. 012038.

13. Rizal, C.; Belotelov, V. Sensitivity comparison of surface plasmon resonance (SPR) and magneto-optic SPR biosensors. Eur. Phys. J. Plus 2019, 134, 435. [CrossRef]

14. Singh, P. SPR Biosensors: Historical Perspectives and Current Challenges. Sensor Actuat. B-Chem. 2016, 229, 110-130. [CrossRef]

15. Kim, D.; Choi, E.; Lee, C.; Choi, Y.; Kim, H.; Yu, T.; Piao, Y. Highly sensitive and selective visual detection of $\mathrm{Cr}(\mathrm{VI})$ ions based on etching of silver-coated gold nanorods. Nano. Converg. 2019, 6, 34. [CrossRef] [PubMed]

16. Rizal, C.; Pisana, S.; Hrvoic, I. Improved magneto-optic surface plasmon resonance biosensors. In Proceedings of Photonics; Multidisciplinary Digital Publishing Institute: Basel, Switzerland, 2018; p. 15.

17. Rizal, C.; Pisana, S.; Hrvoic, I.; Fullerton, E.E. Microstructure and magneto-optical surface plasmon resonance of Co/Au multilayers. J. Phys. Commun. 2018, 2, 055010. [CrossRef]

18. Gupta, B.D.; Kant, R. [INVITED] Recent advances in surface plasmon resonance based fiber optic chemical and biosensors utilizing bulk and nanostructures. Opt. Laser Technol. 2018, 101, 144-161. [CrossRef]

19. Masson, J.F. Surface Plasmon Resonance Clinical Biosensors for Medical Diagnostics. ACS Sens. 2017, 2, 16-30. [CrossRef]

20. Piliarik, M.; Homola, J. Surface plasmon resonance (SPR) sensors: approaching their limits? Optics express. 2009, 17, 16505-16517. [CrossRef]

21. Rippa, M.; Castagna, R.; Pannico, M.; Musto, P.; Zyss, J.; Petti, L. Multi-sensing meta nanostructures with surface-enhanced Raman scattering and surface plasmon resonance functionalities. In Proceedings of the 19th Italian National Conference on Photonic Technologies (Fotonica 2017), Padua, Italy, 3-5 May 2017.

22. Hasan, M.R.; Akter, S.; Rifat, A.A.; Rana, S.; Ahmed, K.; Ahmed, R.; Subbaraman, H.; Abbott, D. Spiral photonic crystal fiber-based dual-polarized surface plasmon resonance biosensor. IEEE Sens. J. 2017, 18, 133-140. [CrossRef]

23. Cheng, C.; Chen, H.-Y.; Wu, C.-S.; Meena, J.S.; Simon, T.; Ko, F.-H. A highly sensitive and selective cyanide detection using a gold nanoparticle-based dual fluorescence-colorimetric sensor with a wide concentration range. Sens. Actuators B Chem. 2016, 227, 283-290. [CrossRef]

24. Mauriz, E.; Garcia-Fernandez, M.C.; Lechuga, L.M. Towards the design of universal immunosurfaces for SPR-based assays: A review. Trac-Trend Anal. Chem. 2016, 79, 191-198. [CrossRef]

25. Guo, T.; Gonzalez-Vila, A.; Loyez, M.; Caucheteur, C. Plasmonic Optical Fiber-Grating Immunosensing: A Review. Sensors 2017, 17, 2732. [CrossRef]

26. Sahu, V.; Gupta, A.; Kumar, R.; Gupta, T.; Mohan, A.; Dey, S. Quantification of Rac1 and Rac1b in serum of non small cell lung cancer by label free real time assay. Clin. Chim. Acta 2016, 460, 231-235. [CrossRef]

27. Vashist, S.K.; Schneider, E.M.; Luong, J.H. Surface plasmon resonance-based immunoassay for human C-reactive protein. Analyst 2015, 140, 4445-4452. [CrossRef]

28. Mohseni, S.; Moghadam, T.T.; Dabirmanesh, B.; Jabbari, S.; Khajeh, K. Development of a label-free SPR sensor for detection of matrixmetalloproteinase-9 by antibody immobilization on carboxymethyldextran chip. Biosen.s Bioelectron. 2016, 81, 510-516. [CrossRef]

29. Makaraviciute, A.; Ramanavicius, A.; Ramanaviciene, A. Development of a reusable protein G based SPR immunosensor for direct human growth hormone detection in real samples. Anal. Methods 2015, 7, 9875-9884. [CrossRef]

30. Lisi, S.; Scarano, S.; Fedeli, S.; Pascale, E.; Cicchi, S.; Ravelet, C.; Peyrin, E.; Minunni, M. Toward sensitive immuno-based detection of tau protein by surface plasmon resonance coupled to carbon nanostructures as signal amplifiers. Biosens. Bioelectron. 2017, 93, 289-292. [CrossRef]

31. Kausaite-Minkstimiene, A.; Ramanaviciene, A.; Kirlyte, J.; Ramanavicius, A. Comparative study of random and oriented antibody immobilization techniques on the binding capacity of immunosensor. Anal. Chem. 2010, 82, 6401-6408. [CrossRef]

32. Ermini, M.L.; Chadtova Song, X.; Springer, T.; Homola, J. Peptide Functionalization of Gold Nanoparticles for the Detection of Carcinoembryonic Antigen in Blood Plasma via SPR-Based Biosensor. Front. Chem. 2019, 7, 40. [CrossRef] 
33. Pawula, M.; Altintas, Z.; Tothill, I.E. SPR detection of cardiac troponin T for acute myocardial infarction. Talanta 2016, 146, 823-830. [CrossRef]

34. Ashaduzzaman, M.; Deshpande, S.R.; Murugan, N.A.; Mishra, Y.K.; Turner, A.P.; Tiwari, A. On/off-switchable LSPR nano-immunoassay for troponin-T. Sci. Rep. 2017, 7, 44027. [CrossRef]

35. Ben Haddada, M.; Hu, D.; Salmain, M.; Zhang, L.; Peng, C.; Wang, Y.; Liedberg, B.; Boujday, S. Gold nanoparticle-based localized surface plasmon immunosensor for staphylococcal enterotoxin A (SEA) detection. Anal. Bioanal. Chem. 2017, 409, 6227-6234. [CrossRef] [PubMed]

36. Loiseau, A.; Zhang, L.; Hu, D.; Salmain, M.; Mazouzi, Y.; Flack, R.; Liedberg, B.; Boujday, S. Core-Shell Gold/Silver Nanoparticles for Localized Surface Plasmon Resonance-Based Naked-Eye Toxin Biosensing. ACS Appl Mater. Interfaces 2019, 11, 46462-46471. [CrossRef] [PubMed]

37. Lee, J.U.; Nguyen, A.H.; Sim, S.J. A nanoplasmonic biosensor for label-free multiplex detection of cancer biomarkers. Biosens. Bioelectron. 2015, 74, 341-346. [CrossRef]

38. Jia, K.; Khayway, M.; Li, Y.; Bijeon, J.-L.; Adam, P.-M.; Déturche, R.; Guelorget, B.; François, M.; Louarn, G.; Ionescu, R.E. Strong improvements of LSPR sensitivity by using Au/Ag bi-metallic nanostructures modified with poly-dopamine films. ACS Appl. Mater. Interfaces 2014, 6, 219-227. [CrossRef] [PubMed]

39. Ma, X.; Lin, Y.; Guo, L.; Qiu, B.; Chen, G.; Yang, H.H.; Lin, Z. A universal multicolor immunosensor for semiquantitative visual detection of biomarkers with the naked eyes. Biosens. Bioelectron. 2017, 87, 122-128. [CrossRef]

40. Zhang, Z.; Wang, H.; Chen, Z.; Wang, X.; Choo, J.; Chen, L. Plasmonic colorimetric sensors based on etching and growth of noble metal nanoparticles: Strategies and applications. Biosens. Bioelectron. 2018, 114, $52-65$. [CrossRef] [PubMed]

41. Inci, F.; Tokel, O.; Wang, S.; Gurkan, U.A.; Tasoglu, S.; Kuritzkes, D.R.; Demirci, U. Nanoplasmonic quantitative detection of intact viruses from unprocessed whole blood. ACS Nano 2013, 7, 4733-4745. [CrossRef]

42. Akira, S.; Uematsu, S.; Takeuchi, O. Pathogen recognition and innate immunity. Cell 2006, 124, $783-801$. [CrossRef]

43. Feldmann, H.; Geisbert, T.W. Ebola haemorrhagic fever. Lancet 2011, 377, 849-862. [CrossRef]

44. World Health Organization. Dengue and Severe Dengue; World Health Organization. Regional Office for the Eastern Mediterranean: Cairo, Egypt, 2014.

45. Lee, J.H.; Oh, B.K.; Choi, J.W. Development of a HIV-1 Virus Detection System Based on Nanotechnology. Sensors 2015, 15, 9915-9927. [CrossRef]

46. Caygill, R.L.; Blair, G.E.; Millner, P.A. A review on viral biosensors to detect human pathogens. Anal. Chim. Acta 2010, 681, 8-15. [CrossRef] [PubMed]

47. Chang, Y.F.; Wang, W.H.; Hong, Y.W.; Yuan, R.Y.; Chen, K.H.; Huang, Y.W.; Lu, P.L.; Chen, Y.H.; Chen, Y.A.; Su, L.C.; et al. Simple Strategy for Rapid and Sensitive Detection of Avian Influenza A H7N9 Virus Based on Intensity-Modulated SPR Biosensor and New Generated Antibody. Anal. Chem 2018, 90, 1861-1869. [CrossRef]

48. Jahanshahi, P.; Zalnezhad, E.; Sekaran, S.D.; Adikan, F.R. Rapid immunoglobulin M-based dengue diagnostic test using surface plasmon resonance biosensor. Sci. Rep. 2014, 4, 3851. [CrossRef]

49. Loureiro, F.C.C.L.; Neff, H.; Melcher, E.U.K.; Roque, R.A.; de Figueiredo, R.M.P.; Thirstrup, C.; Borre, M.B.; Lima, A.M.N. Simplified immunoassay for rapid Dengue serotype diagnosis, revealing insensitivity to non-specific binding interference. Sensing and Bio-Sensing Research 2017, 13, 96-103. [CrossRef]

50. Luo, B.; Xu, Y.; Wu, S.; Zhao, M.; Jiang, P.; Shi, S.; Zhang, Z.; Wang, Y.; Wang, L.; Liu, Y. A novel immunosensor based on excessively tilted fiber grating coated with gold nanospheres improves the detection limit of Newcastle disease virus. Biosens. Bioelectron. 2018, 100, 169-175. [CrossRef] [PubMed]

51. Lee, J.H.; Kim, B.C.; Oh, B.K.; Choi, J.W. Highly sensitive localized surface plasmon resonance immunosensor for label-free detection of HIV-1. Nanomedicine 2013, 9, 1018-1026. [CrossRef]

52. Kim, J.; Oh, S.Y.; Shukla, S.; Hong, S.B.; Heo, N.S.; Bajpai, V.K.; Chun, H.S.; Jo, C.H.; Choi, B.G.; Huh, Y.S.; et al. Heteroassembled gold nanoparticles with sandwich-immunoassay LSPR chip format for rapid and sensitive detection of hepatitis B virus surface antigen (HBsAg). Biosens. Bioelectron. 2018, 107, 118-122. [CrossRef]

53. Salyers, A.A.; Whitt, D.D.; Whitt, D.D. Bacterial Pathogenesis: A Molecular Approach; ASM Press: Washington, DC, USA, 1994; Volume 3. 
54. Park, Y.M.; Lim, S.Y.; Jeong, S.W.; Song, Y.; Bae, N.H.; Hong, S.B.; Choi, B.G.; Lee, S.J.; Lee, K.G. Flexible nanopillar-based electrochemical sensors for genetic detection of foodborne pathogens. Nano Converg. 2018, 5, 15. [CrossRef]

55. Alsan, M.; Schoemaker, L.; Eggleston, K.; Kammili, N.; Kolli, P.; Bhattacharya, J. Out-of-pocket health expenditures and antimicrobial resistance in low-income and middle-income countries: an economic analysis. Lancet. Infect. Dis. 2015, 15, 1203-1210. [CrossRef]

56. Adegbola, R.A.; DeAntonio, R.; Hill, P.C.; Roca, A.; Usuf, E.; Hoet, B.; Greenwood, B.M. Carriage of Streptococcus pneumoniae and other respiratory bacterial pathogens in low and lower-middle income countries: a systematic review and meta-analysis. PLOS ONE 2014, 9, e103293. [CrossRef]

57. Kim, D.W.; Chun, H.J.; Kim, J.H.; Yoon, H.; Yoon, H.C. A non-spectroscopic optical biosensor for the detection of pathogenic Salmonella Typhimurium based on a stem-loop DNA probe and retro-reflective signaling. Nano. Converg. 2019, 6, 16. [CrossRef]

58. Lazcka, O.; Del Campo, F.J.; Munoz, F.X. Pathogen detection: a perspective of traditional methods and biosensors. Biosens. Bioelectron. 2007, 22, 1205-1217. [CrossRef]

59. Mansfield, L.; Forsythe, S. The detection of Salmonella using a combined immunomagnetic separation and ELISA end-detection procedure. Lett. Appl. Microbiol. 2000, 31, 279-283. [CrossRef] [PubMed]

60. Cho, I.H.; Irudayaraj, J. In-situ immuno-gold nanoparticle network ELISA biosensors for pathogen detection. Int. J. Food Microbiol. 2013, 164, 70-75. [CrossRef] [PubMed]

61. Torun, O.; Hakki Boyaci, I.; Temur, E.; Tamer, U. Comparison of sensing strategies in SPR biosensor for rapid and sensitive enumeration of bacteria. Biosens. Bioelectron. 2012, 37, 53-60. [CrossRef] [PubMed]

62. Ahmed, A.; Rushworth, J.V.; Hirst, N.A.; Millner, P.A. Biosensors for whole-cell bacterial detection. Clin. Microbiol. Rev. 2014, 27, 631-646. [CrossRef] [PubMed]

63. Oh, B.K.; Lee, W.; Chun, B.S.; Bae, Y.M.; Lee, W.H.; Choi, J.W. The fabrication of protein chip based on surface plasmon resonance for detection of pathogens. Biosens. Bioelectron. 2005, 20, 1847-1850. [CrossRef] [PubMed]

64. Jyoung, J.Y.; Hong, S.H.; Lee, W.; Choi, J.W. Immunosensor for the detection of Vibrio cholerae O1 using surface plasmon resonance. Biosens. Bioelectron. 2006, 21, 2315-2319. [CrossRef]

65. Taheri, R.A.; Rezayan, A.H.; Rahimi, F.; Mohammadnejad, J.; Kamali, M. Development of an immunosensor using oriented immobilized anti-OmpW for sensitive detection of Vibrio cholerae by surface plasmon resonance. Biosens. Bioelectron. 2016, 86, 484-488. [CrossRef]

66. Makhneva, E.; Farka, Z.; Skladal, P.; Zajickova, L. Cyclopropylamine plasma polymer surfaces for label-free SPR and QCM immunosensing of Salmonella. Sensor Actuat. B-Chem. 2018, 276, 447-455. [CrossRef]

67. Chen, J.; Park, B. Label-free screening of foodborne Salmonella using surface plasmon resonance imaging. Anal. Bioanal. Chem. 2018, 410, 5455-5464. [CrossRef] [PubMed]

68. Masdor, N.A.; Altintas, Z.; Shukor, M.Y.; Tothilll, I.E. Subtractive inhibition assay for the detection of Campylobacter jejuni in chicken samples using surface plasmon resonance. Scientific Reports 2019, 9, 1-10. [CrossRef] [PubMed]

69. Farka, Z.; Jurik, T.; Pastucha, M.; Skladal, P. Enzymatic Precipitation Enhanced Surface Plasmon Resonance Immunosensor for the Detection of Salmonella in Powdered Milk. Anal. Chem. 2016, 88, 11830-11836. [CrossRef] [PubMed]

70. Zou, F.; Wang, X.X.; Qi, F.J.; Kohn, K.; Lee, J.; Zhou, H.J.; Chen, H.X. Magneto-plamonic nanoparticles enhanced surface plasmon resonance TB sensor based on recombinant gold binding antibody. Sensor Actuat. B-Chem. 2017, 250, 356-363. [CrossRef]

71. Zheng, L.; Cai, G.; Wang, S.; Liao, M.; Li, Y.; Lin, J. A microfluidic colorimetric biosensor for rapid detection of Escherichia coli O157: $\mathrm{H} 7$ using gold nanoparticle aggregation and smart phone imaging. Biosens. Bioelectron. 2019, 124, 143-149. [CrossRef]

72. Zhang, L.; Salmain, M.l.; Liedberg, B.; Boujday, S. Naked Eye Immunosensing of Food Biotoxins Using Gold Nanoparticle-Antibody Bioconjugates. ACS Appl. Nano Mater. 2019, 2, 4150-4158. [CrossRef]

73. Arcas, A.D.S.; Dutra, F.D.S.; Allil, R.; Werneck, M.M. Surface Plasmon Resonance and Bending Loss-Based U-Shaped Plastic Optical Fiber Biosensors. Sensors 2018, 18, 648. [CrossRef]

74. Kaushik, S.; Tiwari, U.K.; Pal, S.S.; Sinha, R.K. Rapid detection of Escherichia coli using fiber optic surface plasmon resonance immunosensor based on biofunctionalized Molybdenum disulfide (MoS2) nanosheets. Biosens. Bioelectron. 2019, 126, 501-509. [CrossRef] 
75. Mulcahy, L.A.; Pink, R.C.; Carter, D.R. Routes and mechanisms of extracellular vesicle uptake. J. Extracell Vesicles 2014, 3, 24641. [CrossRef]

76. Witwer, K.W.; Buzas, E.I.; Bemis, L.T.; Bora, A.; Lasser, C.; Lotvall, J.; Nolte-'t Hoen, E.N.; Piper, M.G.; Sivaraman, S.; Skog, J.; et al. Standardization of sample collection, isolation and analysis methods in extracellular vesicle research. J. Extracell Vesicles 2013, 2, 20360. [CrossRef]

77. Wiklander, O.P.; Nordin, J.Z.; O’Loughlin, A.; Gustafsson, Y.; Corso, G.; Mäger, I.; Vader, P.; Lee, Y.; Sork, H.; Seow, Y. Extracellular vesicle in vivo biodistribution is determined by cell source, route of administration and targeting. J. Extracell Vesicles 2015, 4, 26316. [CrossRef]

78. Bu, J.; Shim, J.E.; Lee, T.H.; Cho, Y.H. Multi-modal liquid biopsy platform for cancer screening: screening both cancer-associated rare cells and cancer cell-derived vesicles on the fabric filters for a reliable liquid biopsy analysis. Nano Converg. 2019, 6, 1-8. [CrossRef] [PubMed]

79. Zhang, J.; Li, S.; Li, L.; Li, M.; Guo, C.; Yao, J.; Mi, S. Exosome and exosomal microRNA: trafficking, sorting, and function. Genomics Proteomics Bioinformatics 2015, 13, 17-24. [CrossRef] [PubMed]

80. Théry, C.; Zitvogel, L.; Amigorena, S. Exosomes: composition, biogenesis and function. Nat. Rev. Immunol. 2002, 2, 569. [CrossRef] [PubMed]

81. Alderton, G.K. Exosomes drive premetastatic niche formation. Nat. Rev. Cancer 2012, 12, 447. [CrossRef] [PubMed]

82. Azmi, A.S.; Bao, B.; Sarkar, F.H. Exosomes in cancer development, metastasis, and drug resistance: a comprehensive review. Cancer Metastasis Rev. 2013, 32, 623-642. [CrossRef] [PubMed]

83. Brinton, L.T.; Sloane, H.S.; Kester, M.; Kelly, K.A. Formation and role of exosomes in cancer. Cell Mol. Life Sci. 2015, 72, 659-671. [CrossRef]

84. Picciolini, S.; Gualerzi, A.; Vanna, R.; Sguassero, A.; Gramatica, F.; Bedoni, M.; Masserini, M.; Morasso, C. Detection and Characterization of Different Brain-Derived Subpopulations of Plasma Exosomes by Surface Plasmon Resonance Imaging. Anal. Chem 2018, 90, 8873-8880. [CrossRef]

85. Sina, A.A.I.; Vaidyanathan, R.; Wuethrich, A.; Carrascosa, L.G.; Trau, M. Label-free detection of exosomes using a surface plasmon resonance biosensor. Anal. Bioanal. Chem. 2019, 411, 1311-1318. [CrossRef]

86. Wang, Q.; Zou, L.; Yang, X.; Liu, X.; Nie, W.; Zheng, Y.; Cheng, Q.; Wang, K. Direct quantification of cancerous exosomes via surface plasmon resonance with dual gold nanoparticle-assisted signal amplification. Biosens. Bioelectron. 2019, 135, 129-136. [CrossRef]

87. Im, H.; Shao, H.; Park, Y.I.; Peterson, V.M.; Castro, C.M.; Weissleder, R.; Lee, H. Label-free detection and molecular profiling of exosomes with a nano-plasmonic sensor. Nat. Biotechnol 2014, 32, 490-495. [CrossRef] [PubMed]

88. Thakur, A.; Qiu, G.; Ng, S.P.; Guan, J.; Yue, J.; Lee, Y.; Wu, C.L. Direct detection of two different tumor-derived extracellular vesicles by SAM-AuNIs LSPR biosensor. Biosens. Bioelectron. 2017, 94, 400-407. [CrossRef] [PubMed]

89. Bathini, S.; Raju, D.; Badilescu, S.; Kumar, A.; Ouellette, R.J.; Ghosh, A.; Packirisamy, M. Nano-Bio Interactions of Extracellular Vesicles with Gold Nanoislands for Early Cancer Diagnosis. Research (Wash D C) 2018, 2018, 3917986. [CrossRef] [PubMed]

90. Raghu, D.; Christodoulides, J.A.; Christophersen, M.; Liu, J.L.; Anderson, G.P.; Robitaille, M.; Byers, J.M.; Raphael, M.P. Nanoplasmonic pillars engineered for single exosome detection. PLoS ONE 2018, 13, e0202773. [CrossRef]

91. Wang, Y.F.; Yuan, W.; Kimber, M.; Lu, M.; Dong, L. Rapid Differentiation of Host and Parasitic Exosome Vesicles Using Microfluidic Photonic Crystal Biosensor. Acs Sens. 2018, 3, 1616-1621. [CrossRef]

92. Kotlarek, D.; Vorobii, M.; Ogieglo, W.; Knoll, W.; Rodriguez-Emmenegger, C.; Dostalek, J. Compact Grating-Coupled Biosensor for the Analysis of Thrombin. ACS Sens. 2019, 4, 2109-2116. [CrossRef]

93. Cong, S.; Yuan, Y.; Chen, Z.; Hou, J.; Yang, M.; Su, Y.; Zhang, Y.; Li, L.; Li, Q.; Geng, F.; et al. Noble metal-comparable SERS enhancement from semiconducting metal oxides by making oxygen vacancies. Nat. Commun. 2015, 6, 7800. [CrossRef]

94. Choi, J.H.; El-Said, W.A.; Choi, J.-W. Highly sensitive surface-enhanced Raman spectroscopy (SERS) platform using core/double shell (Ag/polymer/Ag) nanohorn for proteolytic biosensor. Appl. Surf. Sci. 2019, 144669. [CrossRef]

95. El-Said, W.A.; Yoon, J.; Choi, J.W. Nanostructured surfaces for analysis of anticancer drug and cell diagnosis based on electrochemical and SERS tools. Nano Converg. 2018, 5, 11. [CrossRef] 
96. Lee, J.H.; Choi, J.H.; Chueng, S.D.; Pongkulapa, T.; Yang, L.; Cho, H.Y.; Choi, J.W.; Lee, K.B. Nondestructive Characterization of Stem Cell Neurogenesis by a Magneto-Plasmonic Nanomaterial-Based Exosomal miRNA Detection. ACS Nano 2019, 13, 8793-8803. [CrossRef]

97. Mohammadi, S.; Salimi, A.; Hamd-Ghadareh, S.; Fathi, F.; Soleimani, F. A FRET immunosensor for sensitive detection of CA 15-3 tumor marker in human serum sample and breast cancer cells using antibody functionalized luminescent carbon-dots and AuNPs-dendrimer aptamer as donor-acceptor pair. Anal. Biochem. 2018, 557, 18-26. [CrossRef] [PubMed]

C 2020 by the authors. Licensee MDPI, Basel, Switzerland. This article is an open access article distributed under the terms and conditions of the Creative Commons Attribution (CC BY) license (http://creativecommons.org/licenses/by/4.0/). 